\title{
Cellular Morphology
}

National Cancer Institute

\section{Source}

National Cancer Institute. Cellular Morphology. NCI Thesaurus. Code C17768.

Cellular morphology is the form and structure of cells, and its relation to cell function, or the scientific study thereof. 